\title{
DOĞU NAZIM SANATI HAKKINDA BİR ÇALIŞMA (ŞEYH AHMED İBN-İ HUDAYDAD TARAZÎ- FÜNÛNÜ̈'L- BELÂGA)
}

\author{
Metin HAKVERDİĞLLU• \\ İslam JEMENEY*•
}

\section{Öz}

Klasik Türk edebiyatı veya divan edebiyatı adını verdiğimiz edebî dönem yalnızca Batı sahasında, Anadolu'da, gelişmiş değildir. Bu edebiyat; Arap, Fars ve Türk halklarının yüzlerce yıllık ortak aklının ve estetik zevkinin bir ürünüdür. Bu ortaklık, kimi zaman bir dilin zenginleşmesi kimi zaman da bir diğer dilin zayıflaması olarak sonuç vermiştir. Doğu Türklerinin divan edebiyatına katkıları oldukça önemlidir. Bu konu Batı Türkçesi ile Doğu Türkçesi arasındaki coğrafî ve siyasî engellerden dolayı yeterince araştırılmamıştır. İşte Doğu nazım sanatının teorisi hakkında ilk çalışmanın tarihi esasları bu anlamda önemli bir eksikliğe parmak basmaktadır. Şeyh Ahmed ibn-i Hudaydad Tarazî'nin Fünûnü'l-Belâga adlı eseri, Doğu Türklerinin nazım sanatı teorileri hakkında bizlere bir fikir vermektedir. Bu eser, Arap, Fars ve Türk şiirinin temellerini ve sanat anlayışlarını ortaya koymaktadır. Eserin içeriği hakkındaki bu çalışmamız, devrin edebî ve fikrî gelişmesini özetlemesi yönünden önem arz etmektedir. Bu çalışma ile, aruz vezninin gelişimi kısaca ele alınmıştır. Ayrıca edebî sanatlar ve Türk şiir sanatının teorisi hakkında ilk düzenli bilgileri bir araya getiren Ahmed Tarazî'nin Fünûnü'l- Belâga adlı eseri tanıtılmıştır.

Anahtar Kelimeler: Doğu Şiir Sanatı, Şeyh Ahmed İbn-i Hudaydad, Fünûnü'lBelâga, Şiir Dili, Klasik Türk Şiiri.

- Yrd. Doç. Dr., Amasya Üniversitesi Fen Edebiyat Fakültesi, metin.hakverdioglu@amasya.edu.tr.

-. Prof. Dr., Süleyman Demirel Üniversitesi, Kazakistan, jemeneyislam@yahoo.com. 
98 । M. Hakverdioğlu-İ. Jemeney

\title{
A Studied of About East Poem's Art (Shayh Ahmed İbn-i Hudaydad Tarazî- Fünûnü'l- Belâga)
}

\begin{abstract}
The literal period which named classical Turkish literature or diwan literature do not only improve in west or Anatolia. This literature is the product of hundreds of years of collective wisdom and aesthetic pleasure of Arab, Persian and Turkish people. This partnership sometimes makes a language wealthy, sometimes makes other language weak. Contribution of the Eastern Turkish to the diwan literature is very important. This issue has not been investigated because of the geographical and political barriers between Western and Eastern Turkish. So that, the first historical study on the basis of the theory of Eastern poetic art is finger on an important shortcoming. Fünûnü'l-Belâga which has Shayh Ahmed İbn-i Hudaydad Tarazî, gives us information about the theory of Turkish poetic art. This work demonstrates sense of art and fundamentals of Turkish Arab and Persian poetry. This study about the content of Fünûnü'lBelâga is important in terms of summarizing period of the literary and intellectual development. With this study, the development of the aruz poetic measure discussed again. Also the work named Fünûnü'l- Belâga which collected the first regular information about the literary arts and the theory of Turkish poetic art is introduced.
\end{abstract}

Key Words: Eastern poetic art, Shayh Ahmed İbn-i Hudaydad Tarazî, Fünûnü'l- Belâga, poetic language, classical Turkish poetry.

\section{Giriş}

Çok eski zamanlara dayanan ve Türk halklarının manzum eserlerinde yer edinen şiir yapısının teorisi terimini, "ilk defa Kaşgarlı Mahmut, XI. yüzyılda yazdığı Divanü Lügati't-Türk adlı kitabında 'kög'1 olarak kullanmıştır. Kaşgarlı Mahmut, bu kıymetli sözlügüünde anlamını açıklamak istediği şiir parçalarının tamamını kög terimi ile karşılamıştır; ancak biz kög kelimesinin etimolojisini, anlamı ve önemini bugüne kadar açıklayabilmiş değildik. Bu sözlükteki, sanatsal açıklaması yapılan Alp Er Tunga'nın M.Ö. 626'da vefatıyla ilgili sagu örneklerinin üzerinden yaklaşık üç bin yıl geçmiştir. Bu durumda şiir

1 Besim Atalay, Divanü Lügati't-Türk Dizini, c. IV, Türk Dil Kurumu Yayınları, Ankara, 1999, s. 355. 
Doğu Nazım Sanatı Hakkında Bir Çalışmal 99

teorisi hakkında bilimsel ifadelerin, dünyada ilk defa, ulu Turan sahasında ortaya çıkmış olduğunu öngörebiliriz." ${ }^{2}$

Bu bağlamda, İslam'ın Türk şiir sanatına gözle görülen ilk etkisi aruz ölçüsü ile olmuştur.

Bilinen bir gerçektir ki, İslam âleminde şiir teorisi ile ilgili ilk eserler Arap âlimleri tarafından IX. yüzyılda yazılmıştı. İslamiyet'in İran ve Turan topraklarına VII.-VIII. yüzyıllarda yayılmasıyla, Arap dili, Acem sahasinda devlet dili ve bilim dili haline geldi. Bu nedenle İran ve Turan halklarının şiirlerinde Arap ölçüsü, yani aruz vezni hızlı bir şekilde kullanılmaya başlandı.

\section{A. Aruz ve Türk Şiiri}

“VIII. yüzyılda Arap edebiyatında doğan ve bu yüzyıldan başlayarak Arap şiirinde kullanılan bir şiir ölçüsü olan aruz, Arap istilaları ile gittikçe geniş alanları kaplayan Arap kültürü ve edebiyatı ile birlikte İran'a, Afganistan'a, Orta Asya ve Hindistan'a kadar yayılmış ve yavaş yavaş bu yöre halklarının edebiyatlarında kullanılmakta olan bütün değişik şiir ölçülerinin yerini almaya başlamıştır. Önce İran edebiyatını etkisi altına alan aruz, İran şiirindeki değişiklikleri ile öteki edebiyatlara girmiştir." ${ }^{3}$ İpekten'in istila olarak ifade ettiği bu durum Doğu Türklerinin pek çok yazar ve şairi tarafından da dile getirilmiş; ancak her seferinde orta bir yol bulunmuş, edebiyatların aruz ile kayıplarından çok kazançları olduğu ifade edilmiştir.

Aruz vezni, ilk önce İran şiirlerinde kullanıldığı için aruz-1 Farisî yapay şiir ölçüsü olarak ortaya çıtı ve kullanılmaya başlandı. İranlılardan sonra Arap hilafetinin gücüne sahip olan Turan Türkleri, Arap şiir ölçüsünü, yani aruz veznini yoğun olarak kullanmaya başladı.

Bu üstünlük hâlâ bazı Türk halklarının manzum eserlerinde değişmeden devam etmektedir. Bunun en önemli nedeni Türkmen, Azerî, Özbek, Uygur, Tatar v.d. halkların dilinde Arap, Fars kelimelerinin tesirinin büyük olmasıdır. Hatta o halkların dilinde Arap, Fars kelimelerinin değişmeden doğal şekliyle kabullenilmesi sebebiyle onların manzum eserlerinde aruz vezni üstünlügünü sürdürmeye devam edecektir denebilir. "Bu durumun sırrını çok iyi fark etmiş olan

2 İslam Jemeney, Şeyh Ahmed Tarazî- Söz Sanatı/ Fünûnü'l- Belâga, Almatı/Kazakistan, 2013, s. 3.

3 Haluk İpekten, Eski Türk Edebiyatı Nazım Şekilleri ve Aruz, Ötüken, İstanbul, 1994, s. 117. 
100 | M. Hakverdioğlu-İ. Jemeney

Azerbaycan şairi Resul Rıza: 'Yüzyıllar boyunca Azerbaycan şiirinde aruz ölçüsü üstünlüğünü korumuştur. Kelimenin ünlü seslerinin uzun ya da kısa olması temelinde kurulmuş olan bu ölçünün on dokuz çeşit örneği var idi. Aruz ölçüsünü kullanmak ana dilimizi Arap ve Fars kelimeleri ile renklendirdi, hatta bazı kelimelerimizi tamamen değiştirdi. Ancak bunun sonucunda Azerbaycan diline büyük hasar vermiş oldu.' diye bir birine zit düşüncesini bildirerek, bu durumun millî dilleri ters etkilediğini bilimsel açıdan açıklamış oldu."4

Türk halklarının manzum eserlerinde yer alan bu şiir ölçüsü, zamanla aruz-1 Türkî, diye adlandırılmıştır. Özellikle, Çağatay Türkçesinin üstün olduğu dönemlerde ortaya çıkan nazım dünyasında, bu ölçü daha baskın görülmektedir. Aruz-1 Türkî, yayılmaya başladı̆̆ı dönemde, ilk olarak Türk şiir sanatının teorisyeni, Şeyh Ahmed ibn-i Hudaydad Tarazî tarafından telif edilen (1436-1437) Fünûnü'l-Belâga (Söz Sanatı) adlı ilmî çalışmada derinlemesine ele alınmıştır. Bu eser, Kazak sahasında, Taraz şehrinde yazılmıştır. Şeyh Tarazî’den çok sonra Nevaî (1441-1501) ve Babur (1483-1530)'un aruz-1 Türkî şiir ölçüsü hakkında araştırmalar yapıp bu sanatı tanıttı̆̆ını biliyoruz.

Aruz ölçüsü Türkler arasında özellikle divan şiirinde revaç bulmuştur. "Divan şiirinde hâkim vezin aruzdur. Arap şiirinin ölçü sistemi olan aruz, önce Fars şiirinde, ardından aynı medeniyet dairesindeki Türk şiirinde kullanılmaya başlandı. İran edebiyatı teorisyenleri daha 11. yüzyıldan başlayarak aruzu sitemleştirmeye çalıştılar. İan aruz sisteminin yanında Türk aruzundan da bahsetmek mümkündür. Fakat, Türk aruzu, İran aruzunda olduğu gibi bir teorisyenler grubunun çalışmasıyla değil, şairlerin asırlarca denemeyanılma yoluyla ortaya koydukları ürünlerin sonucunda ortaya çıkmıştır." ${ }^{5}$

Muhsin Macit'in yukarıdaki görüşüne ters bir düşünceyi Doğu sahasındaki şiir teorileri çalışmalarında görebiliyoruz. Şeyh Ahmed Tarazî, şiir sanatı hakkında oldukça kapsamlı bir çalışma yapmış ve aruz da dahil pek çok konuyu ayrıntılı ele almıştır. Yani, deneme yanılma çalışması olarak görülen aruz ve şiir sanatı kaideleri, Tarâzî gibi şahsiyetler tarafından çoktan sınırları çizilmiş bir saha haline gelmişti.

4 Jemeney, Şeyh Ahmed Tarazî- Söz Sanatı/ Fünûnü'l- Belâga, s. 3.

5 Muhsin Macit, Divan Şiirinde Ahenk Unsurları, Akçağ, Ankara, 1996, s. 76. 
“Türk şiir tarihinde XVI-XIX. yüzyıllarda aruz-1 Türkî şiir ölçüsüyle yazılan eserlerin şiir yapısını öğrenmek için Şeyh Tarazî̀nin Söz Sanatı olarak adlandırılan XV. asırdaki (1436-1437) eserine bakmak gerekir. Şeyh Tarazî'nin şiir yapısı hakkında yazılan bu teorik bilimsel çıkarımlarına sıkı sıkıya dayanmalıyız. Onun sayesinde Çağatay Türkçesinde yazılan herhangi bir manzum eseri, hangi şiir ölçüsünde ya da hangi türde yazıldığını inceleyerek tanıyabiliriz." 6

Aruz-1 Türkîyi Doğu sahasında takip için şu gerçeğin bilinmesi gerekir: XV. asırda Altınordu İmparatorluğu yıkılmış, onun hakimiyetindeki Türk halkları başka hanlıklara ve beyliklere bölünmüşlerdir. Bu dönemde Türk halklarının edebiyatı tamamen millî yönden ilerlemeye başlamıştır. "XV. asırda başlayan Kazak Hanlığ dönemindeki Kazak edebiyatı, özellikle, onun millî şiir ölçüsü, Kazak şiir ölçüsü, "barmak" vezni temelinde ortaya çıkmıştır. Kazakçada bulunan Farsça-Arapça kelimelerin, Kazak dili seslendirme kurallarına göre telaffuzu, Kazakçalaştırılması neticesinde, Kazak nazmında aruz-1 Türkî şiir ölçüsü yer edinememiştir."7 Ama diğer Türk halklarının dillerindeki Farsça ve Arapça kelimelerin çok olması ve fonetik açıdan değişmeden kabul görmesi ve kullanılması, onların şiirinde aruz-ı Türkî ölçüsünün üstünlüğünü perçinlemiş ve günümüze kadar gelmesini sağlamıştır.

Aruz-1 Türkî hususunda farklı fikirler de yok değildir. Örneğin Resimli Türk Edebiyatı Tarihinde, N. Sami Banarlı aruzun Türk şiirinde doğal olarak yer aldığını iddia etmektedir: “Türklerin savaşlardan barış eğlencelerine; günlük hayatın türlü icaplarına kadar, her hareketlerini musiki ile birlikte yapmaları, Türk şiir lisanına tabiî bir ahenk işlemiştir. $\mathrm{Bu}$ musiki saltanatı eski Türkçeye, kendi hece imkanları içinde bir müzikalite kazandırmıştı. Böyle hecelerle meydana gelen vezin şüphesiz ki aruz değildi; fakat tamamıla parmak hesabına dayanan ve hiçbir ahenk kaidesi teşekkül etmemiş, basit bir hece vezni olmaktan da üstündü. Eski Türk vezninde zaman zaman açı ve kapalı heceleri aruz tef'ilelerini andırır bir ahenkle sıralayan sesler duyuluyordu."8

İşte tüm bu karmaşık gelişim ve anlayışlar içinde Şeyh Ahmed Tarazî̀nin eseri bir mihenk noktası oluşturmakta ve aruzun bilinçli bir

6 Jemeney, Şeyh Ahmed Tarazî̀- Söz Sanatı/ Fünûnü'l- Belâga, s. 4.

7 Jemeney, Şeyh Ahmed Tarazî- Söz Sanatı/ Fünûnü'l- Belâga, s. 8.

8 Nihat Sami Banarlı, Resimli Türk Edebiyatı Tarihi, c. 1, İstanbul, s. 157. 
102 | M. Hakverdioğlu-İ. Jemeney

şekilde Türkler tarafından kabullenildiğini ve geliştirildiğini ispatlamaktadir.

\section{B. Şeyh Ahmed Tarazî ve Eseri Hakkında}

Hakkında hemen hemen hiç bilgi bulunmayan Şeyh Ahmed ibn-i Hudaydad Tarazî Timur hanedanı döneminde yaşamış ve büyük saygı görmüştür. Onu daha çok kendi eserindeki ifadelerinden ve çağının özelliklerini anlayarak tanımak mümkündür. Eserinin ve devrinin değerlendirilmesi onun şahsiyetinin ve ilminin ortaya konması anlamına gelmektedir. Şair ve âlim olduğu eserinden açıç̧a anlaşılan Şeyh Ahmed Tarazî 15. yüzyıl âlimleri arasında zikredilir.

“Şeyh Ahmed ibn Hudaydad Tarazî̀nin 1436-1437 yıllarında yazdığı "Fünûnü'l-Belâga" adlı eseri paha biçilmez bir eser olmakla beraber aynı zamanda çok kapsamlı, derin bir edebî şaheserdir. Şeyh Tarazî̀nin bu kitabı, edebiyat ile medeniyete çok önem vermekte ve onları temellendirmektedir. Onu daima koruyan Emir Timur hanedanının hükmettiği dönemlerde, ilmî ruhun yüksek olduğu ortamda bu eserini yazmıştır. Özellikle, astroloji, tarih ve edebiyat uzmanı Mirza Ulukbek Muhammed Taragay (1394-1449), onun yaşadığ döneme denk gelmiştir." 9 Bu nedenle Şeyh Tarazî kendi eserini Mirza Ulukbek'e ithaf etmiştir. Yazar eserinde: “ilham sahipleri ve gönül sahiplerinden, bu saf cevher hazineden güç alan, eksiklerini düzeltmeye çalışan şair ve yazara hayırlı olsun. Onu dua ederek yad etmek istiyorum ki Ulu Sultan Emir Ulukbek, bütün akıl sahipleri ve ilim dostlarına malum ve ayan olduğu gibi bu eseri, söz sanatının sahasına, belâgat hazinesine kazandıran kişidir. Özellikle, bu değerli kitap, padişahın mübarek adıyla süslenmiştir. $\mathrm{O}$, saltanat denizinin cevheri, adalet sahasının cevheri, cömertlik yağmurunun bulutu, cesurluk ormanının arslanı, feraset âleminin ayı, bilgeliğin padişahı, ulu şahenşah, bilgili şehriyar, kılıç ve kalem ehli, sevgi ve cömertlik deryası; Türk, Arap, Acem halklarının emîridir. Din ve devran yardımcısı Emir Ulukbek Göregen'in, Allah ömrünü uzun, mertebesini yüksek, bahtını, saltanatını daim eylesin... Amin!"10 diye riyasız yazmaktadır.

Şeyh Tarazî bu kitabı ne zaman, nasıl ve hangi amaçta yazdığını şöyle açılamıştır: "Şiir türleri birbiriyle ilişkili olarak bir bütün halinde

9 Jemeney, Şeyh Ahmed Tarazî̀- Söz Sanatı/ Fünûnü'l- Belâga, s. 4.

10 Şeyh Ahmed Tarazî, Fünûnü'l- Belâga, s. 36a. 
herhangi bir eser ya da mecmuada incelenmemişti. Bu nedenle ilgimi çekti. Büyük bir heves ve istekle elime kalem alıp nesir ve şiire ilgi duyanlara genel kuralları hakkında bilgi vermek istedim. Her kim ki söz sanatı ve belâgat yeteneğine sahip ise, bu eserden faydalanacaktır. Uzun zaman bu düşünceyle geçti. En sonunda 840 hicrî yılında (1436-1437) bu ilme başladım. Fars ve Türk kelimelerini birleştirerek, risaleyi yazmayı bitirdim. Onu 'Fünûnü'l-Belâga' olarak adlandırdım. Bazıları ona 'Letâyif-i Tarazî' dedi. İlham ve gönül sahipleri bu tertemiz saf inci ve cevher hazinesinden faydalanarak eksiklerini tamamlamaya çalışırlarsa, şair ve yazarlara hayırlı ola, diye dua ediyorum."11

Bu bağlamda, Ahmed Tarazî̀nin bu eserini Kazakça olarak yayımlayan Prof. Dr. İslam Jemeney'in Şeyh Ahmed Tarazî, Fünûnü'lBelâga (Körkem Söz Hüneri), Almatı/Kazakistan, adlı eserinin makalemizin ana kaynağı olduğunu belirtmemiz gerekir.

Şeyh Ahmed Hudaydad Tarazî'nin eserinin el yazısı 139 yapraktan (278 sayfadan) oluşmaktadır. Bu eserin tek el yazısı nüshası İngiltere Krallığ 1 Oxford şehrinde Bodlean Kütüphanesinde mevcuttur. Bu eserin, Özbek bilim adamları tarafından, 1996 yılında, Arap alfabesinden Kiril harflerine transkribi yapılmıştır.

Yukarıda da belirttiğimiz gibi, Şeyh Tarazî'nin hayatı hakkında, bu eserde herhangi bir bilgi verilmemiştir. "Bize göre, o Tarih-i Raşidî kitabının yazarı Mirza Haydar Duğlat'ın meşhur dedesi olabilir."12

Şeyh Tarazî́nin, ünlü uyumu ile sesbilimi kurallarına uygunluk araştırması, Doğu edebiyatını aruz ilmine göre incelemesi ve bunu Arap, Fars ve Türk şiirlerinden örneklerle ispatlaması, edebiyat teorisinde Türk dünyasına miras bıraktığı büyük bir başarıdır. Onun XV. asırda yazdığı bu, Fünunü'l-Belâga/ Körkem Söz Hüneri/ Söz Sanatı/ Letayif-i Tarazî şeklinde adlandırılan eserinin paha biçilmez değeri herkes tarafından kabul edilmektedir. Bu eserin, Türk edebiyatının (manzum ve mensur) yapısını açılayan, onu daha derin incelememize imkan tanıyan ilk eser olduğunu tekrar tekar belirtmemiz gerekir.

Şeyh Ahmed ibn Hudaydad Tarazî'nin Fünunü'l-Belâga adlı bu eseri, orta asır Türk edebiyatı teorisi hakkında yazılan ilk eserdir. Bu eserin en önemli özelliği, Türk dilinde yazılmış olması, şiir türlerine gösterdiği Türkçe örneklerle beraber Farsça ve Arapça beyitlerde

11 Şeyh Ahmed Tarazî, Fünûnü'l- Belâga, 3a.

12 Jemeney, Şeyh Ahmed Tarazî- Söz Sanatıl Fünûnü'l- Belâga, s. 5. 
104 | M. Hakverdioğlu-İ. Jemeney

kullanmasıdır. Örneğin, şiir tarifine başlarken açılamasını Arapça yazmıştır. Şiirin 10 türü olduğunu söylemiş ve hepsini Arap dilinde yazmıştır:

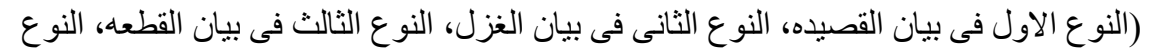

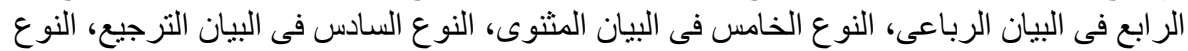

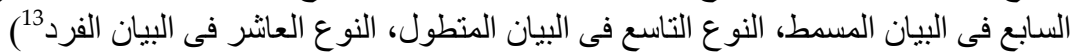

Bununla beraber her bir şiir türüne Türkçe şiir parçaları ile birlikte Farsça şiirlerden örnekler vermiştir.

Fünûnü'l-Belâga dört ana bölümden oluşmaktadır ve her bölümde edebiyatın değişik bir hususiyeti ele alınmaktadır.

Birinci bölümde nazım şekillerinden kaside, gazel, kıt'a, rubaî, tuyuğ, mesnevî, terci'- bend, musammat ve ferdler; Farsça ve Türkçe örnekleri ile ele alınmaktadır.

Kaside nazım şekline verdiği bir örnek beyit (Mevlanâ Lütfî):

Ey cefâ bâbında tasnîf itgüci yüz mekr ü fen

Muttasıl hüsnün sözidür kayda bulsa encümen ${ }^{14}$

Gazel nazım şekli ile ilgili olarak, Şeyh Tarazî, kendi yazdığı bir örneği eserine almıştır:

Ger sabâ ol ay yüzin yed alsa her sa'at nikab

Tâb-1 'ayb tutkanıdın bolgay peşîmân âfitâb

Kâmet-i reftârını gördi meger serv-tîzrev

Reşk ötüdin serv-kadd ü tîzrev oldı kebâb ${ }^{15}$

Kıt'a nazım şekline de Farsça ve Türkçe diğer örneklerin yanına kendi şiirinden bir parça almıştır (Şeyh Ahmed Tarâzî):

Gül yüzüňi görgeli ey reşk-i hûr

Dem be dem gözyaşı kandin dem urar

La'line nisbet 1tar özin ‘akîk

Ol yamanı gör ki kandin dem urar ${ }^{16}$

Rübâî örneği olarak, Farsçadan verilen bol örneklerin arasına, Seyyid Nesimî'den şu Türkçe rubaîyi koymuştur:

13 Jemeney, Şeyh Ahmed Tarazî̀- Söz Sanatı/ Fünûnü'l- Belâga, s. 7. (Birinci kısım kasidenin açıklaması hakkında; ikinci kısım gazelin açıklaması hakkında; üçüncü kısım kıt'anın açıklaması hakkında; dördüncü kısım ruba'inin açıklaması hakkında; beşinci kısım mesnevinin açıklaması hakkında; altıncı kısım terci'in açıklaması hakkında; yedinci kısım mesmudun açıklaması hakkında; dokuzuncu kısım mutedavvel hakkında; onuncu kısım fert hakkındadır.)

14 Jemeney, Şeyh Ahmed Tarazî̀- Söz Sanatı/ Fünûnü'l- Belâga, s. 22.

15 Jemeney, Şeyh Ahmed Tarazî- Söz Sanatı/ Fünûnü'l- Belâga, s. 31.

16 Jemeney, Şeyh Ahmed Tarazî̀- Söz Sanatı/ Fünûnü'l- Belâga, s. 34. 
Ey harâmî gözlerin yağmacıdur

Ka'be yüzündur melâyik hacılar

'Aşkıňa ümmit olan durnacılar

Vey dudagindın hecil helvacilar ${ }^{17}$

Rubaî nazım şeklinde Mevlanâ Sekkâkî'nin şiiri de sanatlı söyleyişinden dolayı eserde örnek olarak kullanılmıştır:

Gülyüzüňi görse bülbül der çemen

Geyçip öz sevdasıdın bolgay çü gen

Lebleriňe tenk tutar özün 'akik

Bilmes o beyhûde sözler ol yaman ${ }^{18}$

Tuyuğ örneğinin en ilginci ise Hacı Akçekindî'ye aittir:

Birgil ey sîmîn zukan elin maňa

Nice yaşı bolgasın ilin maňa

Derdiniz dermân-1 cânımdur menin

Sagınurlar bilmegen itdin maňa ${ }^{19}$

Mesnevî nazım şeklinden bütün örnekleri Farsça veren Tarazî, Mevlanâ Celaleddin-i Rumî'nin Mesnevî adlı eserinin altı beytini de örnek olarak kaydetmiştir.

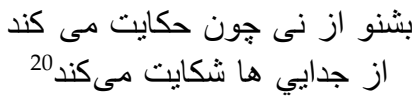

Terci'-bent nazım şeklinde diğer şiirler yanında kendi şiirinden de örnek vermiştir (Şeyh Ahmed Tarazî):

Ey gözleri ‘ayn-1 âfet-i cân

Hüsnü'l-yedâsın sin imdi sultân

Hayvân irür âdemi imastur

Kim dise lebbiňi âb-1 hayvân

Kim sini perî-ge k1lsa nisbet

Tahkîk biliň imasdur insân

Göytürdi gamıň felekniň âyın

Yalguz min imân yüzüň-ke hayrân

Vakt oldı kim eyleseň ter-i ham

Ey 'ârızı reşk-i mâh tâbân

Cân u gönül urtadı firâkıň

17 Jemeney, Şeyh Ahmed Tarazî- Söz Sanatı/ Fünûnü'l- Belâga, s. 37.

18 Jemeney, Şeyh Ahmed Tarazî- Söz Sanatı/ Fünûnü'l- Belâga, s. 37.

19 Jemeney, Şeyh Ahmed Tarazî- Söz Sanatzl Fünûnü'l- Belâga, s. 39.

20 Jemeney, Şeyh Ahmed Tarazî- Söz Sanatı/ Fünûnü'l- Belâga, s. 42. (Dinle neyden kim hikâyet etmede/ Ayrilıklardan şikâyet etmede) 
106 | M. Hakverdioğlu-İ. Jemeney

Endâzedin aştı iştikâkıň

Genç ol ruh u zülfün ejdehâdur

Gamzeniň belî okı yâdur

Her kim ki yüzüň gördü bir dem

'Aşkıň gamı birle mübtelâdur

La'liň ana ki hûn bahâdur

Gamzeň ki töker kanımızı bî-bâk ${ }^{21}$

Musammatlar bölümünde ise muhammes çeşitlerine örnekler veren Tarazî, kendinden şu şiiri almıştır:

Ey 'arızı reşk-i kamer zülfün gamıda her seher

Çîn ü Hoten'de müşk-i ter âşüfte ü şeydâ bolur

Her lahza ey mâh-1 Hoten bulsaň hırâmândır çemen

Feryâd ü nâliş yüz tümen her gûşeden peydâ bolur ${ }^{22}$

Tarazî, müfred örneği olarak şu beyti Türkçe şiirlerden seçmiştir:

Bardur ümmîdüm ki sa'd itgeyler imdi tâli'im

Bes ki yılkıttı felek ehlini efgânım meniň ${ }^{23}$

İkinci bölümde Şeyh Ahmed Hudaydâd Tarazî kafiye ve redif konusunu ele almış ve bu hususta örneklerle açıklamalar yapmıştır. Kafiye çeşitlerini ve revî, ridf, kayd, tesis, redif gibi kavramları tek tek örneklendiren yazar, bu konuda da Türkçe ve Farsça şiir parçaları kullanmıştır.

Ey cemâliňden hacil Firdevs bâgınıň güli

Teşnedür la'liň sıfatın içkeli Kevser müli ${ }^{24}$

Yazar, bu beytte "lam" harfinin revî, "ye" harfinin redif olduğunu belirtmiştir.

Üçüncü bölümde Tarazî, şiir sanatının inceliklerinden bahsetmiş ve örnekler vermiştir.

Meselâ, teşbih sanatı için Celâlî adlı şairden şu beyti örnek olarak almıştır:

Kilur ol göz uğrilukla tutar burç

Anıň tek kim zamâne pâsbânî ${ }^{25}$

Gözü, hırsıza kale alanlara benzetir.

21 Jemeney, Şeyh Ahmed Tarazî- Söz Sanatı/ Fünûnü'l- Belâga, s. 59.

22 Jemeney, Şeyh Ahmed Tarazî- Söz Sanatı/ Fünûnü'l- Belâga, s. 73.

23 Jemeney, Şeyh Ahmed Tarazî- Söz Sanatı/ Fünûnü'l- Belâga, s. 84.

24 Jemeney, Şeyh Ahmed Tarazî- Söz Sanatı/ Fünûnü'l- Belâga, s. 103.

25 Jemeney, Şeyh Ahmed Tarazî̀- Söz Sanatı/ Fünûnü'l- Belâga, s. 170. 
Şeyh Tarazî, iltifat sanatı ile ilgili de şu ilginç örneği vermiştir:

Tüşti işim biringe ki âl bile

Bagladı gönlümni zülfi al bile

Kıble birip cân alurga ey sanem

Bolmasaň râzı gönülni al bile ${ }^{26}$

Birinci dizede "benim" iyeliğini kullanan şair, ikinci dizede "o" zamirini, üçüncü dizede "sen" ve dördüncü dizede yine "sen" zamirini kullanarak iltifat sanatını kullanmıştır.

Neredeyse tüm sanatları örnekleri ile tek tek açıklayan Tarazî, devrine göre oldukça ileri bir belâgat âlimi olduğunu ispatlamıştır.

Dördüncü bölümde yazar, hikayeler ve mesneviler hakkında bilgi vermektedir.

\section{Türkler ve İslam Sanatları ile Tanışmaları}

Tarazî́nin bu eseri kaleme alabilmesinin temel kaynağ 1 onun yetiştiği ortamdır. $\mathrm{O}$, güçlü bir kültür birikimini miras almış ve kendi düşünceleri ile yoğurmuştur. Onu yetiştiren birikim, Türklerin İslamiyet'le tanışması ve onu en iyi şekilde özümsemesi ile kendini göstermiştir. Bu birikimi şöyle özetleyebiliriz:

Türk halkları edebiyatı tarihi, İslamiyet'ten önce ve M.Ö. VI-V. asırda yazılan Efrasiyap (Alp Er Tunga) ağıtlarına dayanır. Doğu Türk dünyasında kabul edildiği şekliyle, Türkçe için M.S. V-VIII. asır eski dönem, M.S. VIII-XV. asır ise orta asırdır. Her iki dönemde şekillenen edebiyat ile medeniyet bütün Türklerin ortak manevî hazinesi olmuştur. Bu iki dönemde Türklerin edebiyat ve ilimde yerleşik ve göçebe hayata has değerleri bu eserlerle ortaya çıkmıştır. Bu sayede Türkler iki kültürlülüğü, yerleşik ve göçebe kültürünün yaşam örneklerini, dünya medeniyetine tanıtmış oldular.

Eski dönemden miras kalan Efrasiyap (Alp Er Tunga) ağıtı ağızdan ağza dolaştıktan asırlar sonra, Mahmut Kaşgarî tarafından derlenip Divanü Lügat-it-Türk adlı eserinde yazıya geçirilmiştir. Dörtlük şeklindeki ağıtlar Türk halklarının edebiyatının başlangıcı olarak bilinmektedir. Sonradan Hoca Ahmed Yesevî'nin Divan-1 Hikmet adlı eserindeki dörtlükler ile bu özellik devam etmiştir. Kazak Hanlığ 1465-1847 döneminde ve sonrasında, Kazak şairleri, şiirlerinde, dörtlük nazım biriminin kullanışlı olduğunu gösterdiler. Bunu, Dulat

26 Jemeney, Şeyh Ahmed Tarazî̀- Söz Sanatı/ Fünûnü'l- Belâga, s. 180. 
108 | M. Hakverdioğlu-İ. Jemeney

Babatayulı, Abay Kunanbayulı, Turmagambet Iztıleuyulı gibi şairlerin eserinde çokça görebiliriz. Kazak edebiyat tarihçileri "dörtlüğü" bazen "dört tagan" veya "dört tarmak" olarak da adlandırmışlardır.

Türklügün eski dönem edebiyatı, bu tarihî- siyasî dönemin sona ermesi ile Turancllık veya Türkistan Dönemi adıyla Yeni Çă̆ olarak devam etti. Artık Türklerin Orta Çağdaki İslamî edebiyat akımı, halkın manevî ve ruhanî kaynağı olmuştur.

İşte bu yeni dönemin ortaya çıkış hikayesini, Şeyh Ahmed Tarazî̀yi yetiştiren dönemin şifrelerini tarihçilerin açıklamalarında bulmak mümkündür:

Tarihî kaynaklarda yazıldı̆̆ 1 gibi, “Kuteybe ibn Müslim (669-715) 704 yılında, Halife Abdülmelik ibn Mervan (685-705 hükmettiği yıllar) tarafından Horasan bölgesinin hükümranı olarak seçildi. Ölümünden sonra Velid ibn Abdümelik babasının yerine hilafet tahtına geçtiği (705715) yıllarda da Kuteybe tahtında kalmaya devam etti. Kuteybe, Horasan'ın hükümranı olduktan sonra, Türk dünyasına İslam-Arap hilafetinin yavaş yavaş nüfûz etmesine sebep olmaya başladı. Onun bu girişimi Harezm'den başladı. Harezm, Amuderyanın iki tarafından Aral gölünün güneyinden Hazar (Kaspi) Denizinin doğusuna kadar alanı kaplayan bölgedir. Amuderya'nın doğu kıyısında bulunan Kat şehri merkez idi. Sonradan Kat ismi Harezm ismiyle değiştirildi. Bu bölgeyi yöneten Harzemşah sülalesi arasındaki sorunlar yüzünden, tahta talip olan adaylardan biri Arap asıllı Kutaybe ibn Müslim'e Harezm'i fethetmesini istediğini bildiren mektup gönderdi. Kutaybe onun ricasını gerçekleştirdi ve 712 yılında hükümete karşı grupların yardımıyla kolaylıkla Harezm'i fethetti. Kutaybe o sirada Buhara, Semerkant, Sogd, Şaş, Fergane, Harezm ve diğer bölgeleri fethettikten sonra Horasan'a geri döndü ve Merv şehrini de Horasan bölgesinin başkenti yaptı. Böylece büyük Horasan bölgesini (eyaletini) kurdu. Eskiden Turan Türk eli olarak bilinen bu saha, Kuteybe'nin Türk ülkelerine yaptığ seferler sonucu Türkistan adıyla tarihe geçti.

Kuteybe'nin zaferleri de Türkleri tamamen kendine boyun eğdiremedi. Sadece Muaviye ibn-i Ebusüfyan yönetimindeki Emevîler, Abbasîler tarafından 750 yılında yıkıldıktan sonra Türkistan'da yeni değişiklikler vuku' buldu". ${ }^{27}$

27 Jemeney, Şeyh Ahmed Tarazî̀- Söz Sanatı/ Fünûnü'l- Belâga, s. 8. 
Abbasî halifesi iyice yerini sağlamlaştırdıktan sonra, 751 yılında Türk ve İslam ordusu, Çin ordusuna karşı Atlak/Talas bölgesinde büyük zafere ulaştı. Bundan sonra Türkler İslam dininin bütün siyasî ve manevî değerlerini derinden hissederek mantıkla kabullenmeye başladı. (751 yıldaki bu olay, Arap asıllı tarihçi İbn Esir'in yazılarıyla beraber Çin belgelerinde de kaydedilmiştir).

İslam-Arap hilafeti, siyasî üstünlüğü ile birlikte kültürü ve İslamî bakış açısı vasıtasıyla, Türk eline nüfuz etti, onu sardı ve derinlere kök saldı. Böylece Türk sahasında edebiyat, yeni çeşitleri ile beraber yeni konular ve temalar ile zenginleşti. Bu başlangıç Arap, Fars, Türk medeniyetlerin kesişmesiyle kendine özgü tarihî-siyasî özellikleri geliştirdi. Bunun önemli sonuçlarından biri, Arapçanın İslam dili olarak ilk asırlarda siyasî açıdan üstün olması; bir diğeri ise Farsça ve Türkçe'nin onun gölgesinde kalmasıdır. Bu durum 2-3 asır devam etti; hatta Farsça ve Türkçe kullanılmamaktan dolayı unutulmak üzereydi.

Bu dönemde Arapçanın üstünlüğünün bir kaç nedeni vardır:

1. Arapçanın Kur'an-1 Kerim dili olması ve bununla beraber Peygamber efendimizin (s.a.s) tercüme alanına önem vermesi ve dönemin büyük medeniyetleri olan Yunan, İran, Hind milletlerinin her türlü alanda yazılı eserlerinin Arapçaya çevrilmesini emretmesi idi. Peygamber efendimiz tarafından emredilen ve desteklenen bu tercüme ve çevirme seferberliği, 850 yılına kadar asrın bütün ilmî ve edebî şaheserlerini tercüme etmeyi başardı. Kur'an-1 Kerim temelinde, Arapça, başka bilimsel alanlarla da zenginleşip kendi döneminin bilimsel sözlük hazinesini zenginleştirdi. Bu nedenle ulu düşünürler, âlimler Arapçaya ihtiyaç duymaya başladılar. Ebu Nasre'l-Farabî, Harezmî, İbn Sinâ, Zekerya Razî ve yüzlerce Türkistanlı, İranlı bilim adamları Arapça öğrenip Arapça okuyup yazmaya başladılar.

2- İslam hilâfetinin yönetimi Araplarda olduğu için siyasî yönetime yakın olan Türk ve Fars devlet adamları da Arapçayı öğrenmeye ihtiyaç duydular.

3- Ekonomik ve iktisadî durumun genişlemesi ve güçlenmesi de Arapçanın gelişmesini destekledi.

İslam dini, Arap, Fars ve Türklerin kendi aralarında sıkı ilişkide olmaları sayesinde, ilmin hızlı bir şekilde yayılmasına ve gelişmesine temel teşkil etti. Arap, Fars ve Türk sahasındaki şehirlerde halka hizmet eden kültür ve bilim merkezleri açıldı. Yani, medreseler, camiiler yanındaki kıraathaneler, kütüphaneler, hangahlar ile kitapçılar faaliyet 
110 | M. Hakverdioğlu-İ. Jemeney

göstermeye başladılar. VIII. asır sonlarında Bağdat şehrinde yüzlerce kitapçı, tercüme merkezleri ve camiler yanında kütüphaneler vardı. Irak'ta Musul şehrinde 950 yılında zengin biri tarafından büyük bir merkezî kütüphane yapıldı. Öğrenciler kitapla beraber gerekli kağıdı oradan alabiliyorlardı. Bütün Müslüman şehirlerde merkezî kütüphaneler gece gündüz, 24 saat, çalışmakta idi. İslam ülkelerinde yazarlar, şairler ve bilim adamları büyük saygı ve hürmete sahip olduklarından, onlar, öğrencileri şehir meydanlarında açık alanda toplayıp dersler vermeye başladılar ve bunu bir gelenek haline getirdiler. O dönemde ilim sahibi olan esir ve köleler azat edildi ve kızerkek çocuklarını, 6 yaştan itibaren, umuma açık olan medreselerde okutabildiler. Umuma açık olan medreselerde eğitim bedava idi, ücretli olan medreselerin de ücreti çok düşüktü. Böylece herkes eşit ve aynı derecede eğitim ve öğretim alabiliyordu. İslamiyet'in bu altın devrinde İran'ın Rey, Irak'ın Bağdat, Musul şehirleri ile beraber Basra şehri; Türkistan'da Merv, Harezm, Taraz, Balasagun ve birçok diğer bilim merkezleri vardı. Bu üç milletin topraklarında yüzlerce medrese, kütüphane, kitapçıların olması kitap okur halkın sayısının çoğalmasına sebep oldu. Bu durum aynı zamanda, ticaretin ve kervan yollarının bu sahalarda genişlemesine ve faal olmasına sebep oldu. Dolayısıyla birçok kişinin gelir kaynağı oldu. O dönem kervanların taşıdıkları en değerli ve kıymetli mal kitap idi. Böylece İslamiyet, İslam medeniyeti ve düşüncesi temelinde tasavvuf edebiyatı gelişti. Orta Çağda bilim ve edebiyatın gelişmesi çok hızlı oldu. "Bu nedenle günümüzde dünyada, Arapça 600 'den fazla el yazısı nüsha bulunmaktadır. Farsça' da iki bine yakın, Türk dilinde on binlerce yazma nüsha, dünyada birçok ülkenin yazma nüshaları merkezlerinde bulunmaktadır." 28

İslam tarihinde bir gerçeği gözden kaçırmamalıyız. Bu gerçek şudur: "Bahsedilen üç milletin ilmî gelişmesi ile beraber toplum arasında da Arapça'nın üstün olması gayet doğal idi. Bu durum Ümeyye halifesinin (661-750) hükmettiği yıllarda en uç noktaya geldi. $\mathrm{Bu}$ dönemde, Ümeyye siyasetinde Araplar dişındaki diğer ırk mensuplarının hor görülmeleri ve İranlılara Acem denmesi İranlılara ağır geldi. Bu nedenle İran milliyetçileri Arapların millî siyasetine karşı gelmeye başladılar. Neticesinde halifeye karşı İran isyancılarına önderlik yapan Ebu Müslim Horasanî zafere ulaşıp, Ümeyye hanedanını

28 Jemeney, Şeyh Ahmed Tarazî- Söz Sanatı/ Fünûnü'l- Belâga, s. 10. 
hilafetten indirip, Abbasî sülalesinin hilafet tahtına oturmasına sebep oldu." 29

Abbasî hilafeti (750-1258) gayrimüslimlere karşı 1lımlı bir siyaset uyguladi. Buna rağmen Arapça'nın tesirinde İran'da Farsça unutulurken, dili Farsça, dini İslam, Sünni-Hanefi olan Samanî sülalesi, halifenin isteği ve emriyle Horasan ile Maveraünnehir'de (875-999) yönetimin başına geçti. Horasan emiri olan Mansur ibni Saman, Fars tarihi ve medeniyetine olan sevgisi ve yoğun ilgisi yüzünden eski İran tarihinin kaynaklarını derleyip topladı. Yeni Farsî-Darî dilinde nesir türünde çeviriler yapıldı. Bu esere Şehname-i Mansurî adı verildi. Bu kitap İran'ın eski dönem padişahlarının hayatını anlatan eser idi. Emir Mansur'un ölümünden sonra bu nüsha genç şair Abülkasım Firdevsî'nin eline geçti. Şair, Şehname-i Mansurî mecmuasını eklediği bölümler ile nesirden nazma çevirdi. Halk tarafından sevilen bu nüsha Şehname-i Firdevsî adıyla günümüze kadar gelmiş oldu. "Şehname" şiiri, İran halkının Farsçaya olan hürmet ve saygısının artmasına sebep oldu ve Farsçanın canlanmasına ve güçlenmesine büyük destek oldu. “Firdevsi'nin de amacı Fars milletinin millî şuurunu uyandırmaktı. Şairin amacını kendi şiirlerinde görebiliriz:

Otuz yıl aşkın çile çektim, ana dilimi canlandırdım, Sayesinde Farsları kendi diline yönelttim,

Zamanenin fırtınaları ve kasırgaları bile yok edemez,

Güzel, muhteşem sarayı ben sözle inşa ettim." ${ }^{30}$

Firdevsî, millî, yüksek idealleri sayesinde günümüzde de İran'ın millî şairi olarak bilinmektedir. Firdevsi'nin Şehname'si İranlılarla beraber Türklerin de Farsçaya olan ilgilerini çoğalttı. Bu nedenle Türk bilim adamları ve şairleri Farsça öğrenmeye başladılar. Böylece Türkçe; Arapça ve Farsça tesiri altında kendi öz yapısından uzaklaşmaya başladı. "Bu sırada Türklerde Karahanlı sülalesi yönetimde idi (8401212). Karahanlılar, Türklerin millî birlik beraberliğini korumak için tek yolun Türk halkının dil, din ve düşünce birliği olduğunu öne sürdüler. $\mathrm{Bu}$ nedenle Karahanlılar memleketin resmi dinini İslamiyet'in SünnîHanefî kolu olarak ilan etti. Türkçe eserler yazılmasına dikkat çekti. Bu dönemde Yusuf Balasagun didaktik Kuttı bılıg (Kutadgu Bilig), Kaşgarlı Mahmut Divanü Lugat-it Türk, Hoca Ahmed Yesevî tasavvuf içerikli

29 Jemeney, Şeyh Ahmed Tarazî- Söz Sanatı/ Fünûnü'l- Belâga, s. 9.

30 Jemeney, Şeyh Ahmed Tarazî̀- Söz Sanatı/ Fünûnü'l- Belâga, s. 11. 
112 | M. Hakverdioğlu-İ. Jemeney

Divan-ı Hikmet adlı eserini Türkçe yazdı. Onlar bu şekilde Türkçülük şuurunun uyanışı ve yeni dönemin başlangıç pınarı oldular. Zamanın siyasi gücü ile aydınların hedefledikleri amaçlarına ulaştıklarına tarih şahittir. Çünkü Türk halkları günümüze kadar, İslamiyet'in SünnîHanefî mezhebini, Türk dilini ve örf-âdetini korumuşlardır. O dönemdeki edebî eserlerin etkisi, edebiyatın, millî ideolojiyi gerçekleştirmede önemli bir araç olduğunu da ispatlamaktadır." ${ }^{31}$

Firdevsî kendi eseriyle İran halkının millî şuurunu uyandırıp, önemli hizmette bulunduğu gibi, Hoca Ahmed Yesevî de Türklerle birlikte İslam dünyasının medenî-siyasî sahasına ölçüsüz hizmette bulunmuştur. Hoca Ahmed Yesevî önderliğinde İslamî tasavvuf edebiyatı Bahaeddin Nakşibendî, Hacı Bektaş, Âşık Paşa (1272-1333), Yunus Emre (1238-1320), Beket Ata (1750-1813) gibi sufî şairler ile Orta Asya ve Anadolu Türk halklarının manevî bütünlügünü bugüne kadar sürdürmüşlerdir.

Bu devirde, İslam'a dayanan edebiyat ve bilim alanları hızlı bir şekilde gelişmeye başlamıştır; öyle ki 750-1050 yılları arasındaki dönem İslam medeniyeti, Rönesans Döneminde, Avrupa'da ilmin gelişmesine ve ilerlemesine temel teşkil etmiştir. Ona Arap, Fars ve Türk düşünürleri, aydınları hep beraber sınırsız katkıda bulunmuşlardır. Edebiyat çeşitli türlerde, ilim çeşitli dallarda büyük başarılara ulaşmış ve Muhammed ibn Musa Harezmî (780-850) cebir ve logaritma ilmini dünyaya tanıtmıştır. Ebu Nasr El-Farabî (870-940) felsefe, mantık, müzik gibi alanları en yüksek dereceye ulaştırmıştır. Öyle ki, Ebu Reyhan ElBeyrunî (973-1048|50) nin tarih, matematik, astronomi, coğrafya, fizik, tıp, jeoloji, mineraloji, v.b. bilim dallarında yazdığı Kanun adlı eseri XXI. asrın eşiğinde Rusça'ya çevrilip, 12 cilt olarak 30000 adet basılmıştır. Bunlar, İslamiyetin ilimdeki gerçek ve net başarısıdır, diyebiliriz. "Bu dönemlerde İslam dünyasında ilimin gelişmesi ve ilerlemesini inceleyen Jorj Sarton, İslam'ın ilmî dönemini yedi bölüme ayırarak, her dönemin başlamasına ilmî yenilikler getiren bir bilim adamının adını vermiştir. Eserinde,

1- Cabir ibn Hayyan dönemi VIII. asrın ikinci yarısı,

2- Muhammed Harezmî dönemi IX. asrın ilk yarısı,

3- Zekerya Razî dönemi IX. asrın ikinci yarısı,

4- Mesûydî dönemi $X$. asrın ilk yarısı,

31 Jemeney, Şeyh Ahmed Tarazî- Söz Sanatı/ Fünûnü'l- Belâga, s. 11-12. 
5- Cuzcanî dönemi X. asrın ikinci yarısı,

6- Beyrunî dönemi XI. asrın ilk yarısı,

7- Ömar Hayyam dönemi XI. asrın ikinci yarısı olarak sınıflandırılmıştır." 32

İnsanlığın bilgisine 1şık saçan bu dönemlerde Arap, Fars ve Türk âlimleri, hangi urk ve etnik gruptan olduğuna bakmadan İslam dininin gelişmesine kalben, aklen yorulmadan hizmette bulundular. Bunun neticesinde bir yandan dünya ilminin hizlı gelişmesine sebep oldular, bir yandan da bu üç millet dünya medeniyeti kervanı ile ilerlemeye devam etme imkanı buldular. Türkler, Türklük düşüncesiyle beraber, İslam'ın tarih görüşünü şairleri ve âlimlerinin eserleri sayesinde tanıyabildiler. Böylece dünya edebiyatına etki ve tesir edebildiler. Buna örnek olarak Orta Çağ ve XV. asır yazarlarından bahsedebiliriz.

Tarazî̀ye uzanan bu medeniyet yolculuğunda, Türkistan sahasında yetişmiş büyük âlimlerin İslam medeniyetine hizmetlerini ve çalışmalarını üç sınıfta inceleyebiliriz:

1- Eserlerini Arapça yazanlar: Muhammed ibn Musa Harezmî (770-850), Ebu Nasr el-Farabî (870-940), Ayazan Ebu Reyhan El-Beyrunî (973-1048/50), Ebu Ali ibn-i Sinâ (980-1037).

2- Eserlerini Farsça yazanlar: Nizami Gencevî (1141-1209), Mevlana Celaleddin-i Rumî (1207-1273).

3- Eserlerini Türkçe yazanlar: Yusuf Balasagun, Kaşgarlı Mahmut, Hoca Ahmed Yesevî (1041-1167), Ali Şir Nevaî (1441-1501), Zahirüddin Muhammed Babür (1483-1530). Bu listeye daha da devam edebiliriz. Bu yüzden VIII-XV. yüzyıllara ait İslam medeniyetinin en büyük muazzam yapıtları Arap, Fars ve Türklerin ortak manevî hazinesi olarak kabul edilmektedir. Bu dönemin âlimlerinin ve yazarlarının büyük kısmı Sünnî-Hanefî mezhebinden oldukları için İslam medeniyetinin hızlı gelişmesine bu inanç yön vermiştir, diyebiliriz.

\section{Sonuç}

Türkler, İslam medeniyetini yalnızca bilim alanında desteklemek ve korumakla sinırlı kalmayıp, onun siyasî tartışmalar ve çımazlardan da sağ salim çıkmasına ve büyük zaferlere ulaşmasına ciddi yardımda bulunmuştur. Türk kavimleri arasından İslamiyet'in güçlenmesi,

32 Jemeney, Şeyh Ahmed Tarazî- Söz Sanatı/ Fünûnü'l- Belâga, s. 12. 
114 | M. Hakverdioğlu-İ. Jemeney

gelişmesi ve yayılmasına, yılmadan çaba gösteren Şeyh Ahmed Tarazî gibi birçok şahsiyetleri söyleyebiliriz.

İslam dininin dünyanın dört bir yanına yayılması ve güçlenmesine İslam tarihindeki dört halifeden sonra, Karahan Buğra, Seyfeddin Kutuz, Sultan Baybars, Fatih Sultan Mehmet'in büyük yardımları ve hizmetleri olmuştur.

Eğer tarihe tarafsız bakacak olursak, İslam medeniyetinin şekillenmesine, kalıplaşmasına, yayılmasına Arap, Fars ve Türk milletleri elbirliği ile maddi ve manevî yardımda bulunmuşlardır. Siyasî çatışmalara bakmadan, aydınlar ve halk, İslam anlayışının, saf tertemiz pınarından yararlanıp, ona hizmet edip büyük yardım ve katkıda bulundular. İslam dininin bütün insanlığın ortak değeri olduğunu kan ve terle; ruhen ve bedenen, kalben ve aklen ispatlamaya devam ettiler, etmektedirler. İslam, insanoğlunun dinidir. Türklerin orta asır edebiyatını; kutsal Kur'an-1 Kerim, İslam büyükleri ve İslam tarihine dayandığı için bu tarih ile medeniyetini Araplar ve Farslardan ayırarak inceleyemeyiz. Bunun kanıtı olarak Şeyh Ahmed Hudaydad Tarazî̀nin "Fünûnü'l-Belâga" adlı eserini gösterebiliriz. Bu eser yukarıda saydığımız temel eserlerden biridir ve hem Türklerin edebî zenginliğinin derinliğini kanıtlar hem de ortak zenginliğin değerini ortaya koyar. Bu eserle, aruz-dil ilişkisi, eser-medeniyet ilişkisi tekrar kanıtlanmış ve İran, Turan, Arap kültürünün zit ve benzer yönleri ile bir medeniyet doğurduğu açıkça belirtilmiştir.

\section{Kaynakça}

Atalay, Besim, Divanü Lügati't-Türk Dizini, Türk Dil Kurumu Yayınları, Ankara, 1999.

Banarlı, Sami Banarlı, Resimli Türk Edebiyatı Tarihi, İstanbul, 1977.

İpekten, Haluk, Eski Türk Edebiyatı Nazım Şekilleri ve Aruz, Ötüken, İstanbul, 1994.

Macit, Muhsin, Divan Şiirinde Ahenk Unsurları, Akçă̆, Ankara, 1996.

Şeyh Ahmed Tarazî, Orijinal Elyazması Metin.

Jemeney, İslam, Şeyh Ahmed Tarazî̀- Söz Sanatı/ Fünûnü'l-Belâga, Almatı/ Kazakistan, 2013. 